\title{
UPPER AIRWAY EVALUATIONS OF THOROUGHBRED RACEHORSES IN A PRIVATE CLINIC IN CURITIBA, BRAZIL - RESTING ENDOSCOPIC FINDINGS IN 587 HORSES
}

\author{
Pedro H. Kaiseler ${ }^{1}$, Bruna Dzyekanski1, Richard Schiefelbein ${ }^{1}$, Rafael G. Silveira ${ }^{1}$, \\ Cláudia T. Pimpão ${ }^{1}$, Pedro V. Michelotto Jr. ${ }^{1}$ \\ 1 PUCPR \\ Correspondência: Pedro V. Michelotto Jr: michelottojunior@yahoo.com.br
}

\begin{abstract}
Obstructive upper airway diseases are an important cause of poor performance in athletic horses. The present study aimed to determine the prevalence of common URT abnormalities (pharyngeal lymphoid hyperplasia - PLH, dorsal displacement of the soft palate - DDSP and recurrent laryngeal neuropathy - RLN) in a population of Thoroughbred racehorses in training submitted to resting endoscopy in a private clinic in Curitiba, Paraná, Brazil. 587 URT resting endoscopies, 3852 year-old and 2023 -year-old-plus horses, were performed during the period of the study and the clinical records of all the examinations were reviewed and analysed. $340(57.9 \%)$ horses were evaluated for routine athletic follow up, $15(2.6 \%)$ were pre-purchase examinations, 83 $(14.1 \%)$ were examined as an investigation for cough, $58(9.9 \%)$ horses had poor performance, 48 $(8.2 \%)$ had abnormal respiratory noise, $35(6.0 \%)$ had epistaxis and $8(1.4 \%)$ had nasal discharge. PLH grades III and IV was diagnosed in $198(33.7 \%)$ horses and was more prevalent in the 2-yearold group than in the older horses $(40.5 \%$ vs. $20.8 \%, p<0.05)$. DDSP was identified in $185(31.5 \%)$ horses, grade III RLN in $13(2.2 \%)$ and grade IV was seen in $21(3.6 \%)$ horses. The present study gives a prevalence of upper airway abnormalities in resting endoscopic evaluation in a racehorse population in Brazil.
\end{abstract}

Key Words: airways; equine; pharyngeal lymphoid hyperplasia; soft palate

\section{AVALIAÇÕES DAS VIAS AÉREAS SUPERIORES DE CAVALOS DE CORRIDA PURO-SANGUE EM UMA CLÍNICA PARTICULAR EM CURITIBA, BRASIL - ACHADOS ENDOSCÓPICOS EM REPOUSO EM 587 CAVALOS}

RESUMO: As doenças obstrutivas das vias aéreas superiores dos cavalos são importante causa de queda de rendimento desportivo. O presente trabalho visou determinar a prevalência das anormalidades das vias aéreas superiores (hiperplasia folicular linfoide - HFL, deslocamento dorsal do palato mole - DDPM, neurolaringopatia - NLP) em uma população de cavalos puro sangue inglês de corrida em treinamento, e submetidos à avaliação endoscópica em repouso em uma clínica privada em Curitiba, Paraná, Brasil. Durante o período do estudo foram realizadas 587 endoscopias, 385 em potros de dois anos de idade e $202 \mathrm{em}$ cavalos de 3 ou mais anos de idade, sendo que todos os registros foram analisados. Dentre os cavalos avaliados, $340(57,9 \%)$ foram avaliados como rotina em acompanhamento atlético, $15(2,6 \%)$ eram exames pré compra, 83 $(14,1 \%)$ deles foram investigações por tosse, $58(9,9 \%)$ cavalos apresentavam queda de rendimento desportivo, $48(8,2 \%)$ tinham ruído respiratório anormal, $35(6,0 \%)$ apresentaram epistaxe e 8 $(1,4 \%)$ cavalos foram avaliados devido a corrimento nasal. HFL graus III e IV foi diagnosticada em $198(33,7 \%)$ dos cavalos, sendo mais prevalente nos potros de dois anos de idade em relação aos mais velhos $(40,5 \%$ vs. $20,8 \%, p<0,05)$. DDPM foi identificado em $185(31,5 \%)$ dos cavalos, enquanto NLP grau III foi encontrada em 13 (2,2\%) e NLP grau IV em 21 (3,6\%) dos cavalos avaliados. O presente trabalho fornece uma prevalência de anormalidades das vias aéreas superiores, encontrada em avaliação endoscópica em repouso, em uma população de cavalos de corrida no Brasil.

Palavras-chave: vias aéreas; equinos; hiperplasia folicular linfóide; palato mole 


\section{INTRODUCTION}

Obstructive upper airway diseases are an important cause of poor performance in athletic horses (Martin et al., 1999; Ducharme, 2005; Tan et al., 2005; Lane et al., 2006a). Due to an increased resistance to airflow, these results in an exacerbation of exerciseinduced hypoxemia (Sánchez et al., 2005).

Resting upper respiratory tract (URT) endoscopy enables the identification of structural abnormalities through investigation of the nasal meati, pharynx, larynx, trachea and auditory tube diverticula in the standing horse (Lane et al., 2006b). Dorsal displacement of the soft palate (DDSP) and recurrent laryngeal neuropathy $(\mathrm{RLN})$ are two of the most common obstructive diseases affecting the URT in horses (Martin et al., 1999; Lane et al., 2006a). These obstructions result in airflow turbulence during expiration in DDSP and inspiration in RLN, consequently impairing performance.

Pharyngeal lymphoid hyperplasia (PLH) is another common finding in young TB racehorses but its prevalence decreases as horses become older (Hobo et al., 1995). Increased grades of pharyngeal lymphoid hyperplasia have not been associated with poor performance (Auer et al., 1985) but evidence suggests that regional inflammation of the upper airway may predispose horses to obstructive upper airway disease, such as nasopharyngeal collapse, dorsal displacement of the soft palate, and aryepiglottic fold collapse (Holcombe, 2006).

The adverse effects of URT obstructive diseases on the thoroughbred (TB) racing industry have been well recognised around the world. However, there is little available information regarding the prevalence of these disorders in South America.
- resting endoscopic findings in 587 horses

The purpose of this study was to determine the prevalence of three common URT abnormalities (PLH, DDSP and RLN) in a population of TB racehorses in training submitted to resting endoscopy in a private clinic located in Curitiba, south of Brazil, to examine if associations existed between the disorders studied, and to investigate if its prevalence varied according to the motive for endoscopic examination. In addition, the findings of this study were compared with previous research conducted in different countries.

\section{MATERIAL AND METHODS}

\section{Inclusion Criteria}

587 URT resting endoscopies of TB racehorses in training were performed between June 1992 and October 2007 in an equine clinic located at the Jockey Club of Paraná in the city of Curitiba, Brazil. The clinical records of all the examinations were reviewed and analysed according to age and complaint at the time of endoscopic examination.

The horses were submitted to the endoscopic examination for routine athletic follow-up, abnormal respiratory noise, poor performance, nasal discharge, cough, epistaxis, and prepurchase examination. In order to study the age difference in the prevalence of the abnormalities, the horses were divided into two groups: (1) two years of age and (2) three years of age and older.

\section{Endoscopic examination}

The endoscopic examination was performed on the resting, unsedated animal. Only a mechanical restraint was used (twitch). The examinations were undertaken by the same professional, including the evaluation of the airways to the carina. However, in the scope of the present study, only the findings of the URT were considered. 
A flexible Olympus CF-140-L fiberscope (Olympus, Lake Success, New York, USA) with a working length of $168 \mathrm{~cm}$ and $12.9 \mathrm{~cm}$ in diameter was inserted in the right nostril and advanced along the ventral meatus until the nasopharynx. The presence of lymphoid follicles was recorded and PLH was graded from I - IV (Raker and Bowles, 1978). Briefly, Grade I was attributed to horses presenting with a pharynx with a few small white follicles over the dorsal wall. Grade II was assigned when numerous small follicles were present with concurrent hyperaemic follicles covering the dorsal and lateral pharyngeal walls. Grade III was assigned when large, hyperaemic grouped follicles over the entire dorsal and lateral walls of the nasopharynx were observed. Grade IV was ascribed to horses presenting with large, oedematous, hyperaemic follicles covering all the pharyngeal mucosa (frequently forming polypoid aggregates). Grades III and IV were considered as abnormal (Holcombe, 2006).

The soft palate was observed during the initial URT evaluation and after tracheal examination. DDSP was considered an abnormality only when detected in the initial evaluation. The concomitant presence of ulcers in the free edge of the soft palate was registered.

The arytenoid cartilage's movement and symmetry was observed and graded from I - IV (Rakestraw et al., 1991): Grade I - synchronous and full abduction of the arytenoid cartilages; Grade II - asynchronous movement (hesitation, flutter, abduction weakness, etc.) of the left arytenoid cartilage during any phase of respiration with full abduction of the left arytenoid cartilages (when referenced to the right) during swallowing or nasal occlusion; Grade III - asynchronous movement (hesitation, flutter, abduction weakness, etc.) of the left arytenoid cartilage during any phase of respiration (full abduction of the left arytenoid cartilages (when referenced to the right) cannot be induced either by swallowing or nasal occlusion); Grade IV (laryngeal hemiplegia) - Midline or paramedian position of the left arytenoid cartilage and no substantial movement of the left arytenoid cartilage during swallowing or nasal occlusion. Grades III and IV of RLN were considered abnormal (Anderson et al., 1997).

Swallowing (induced by touching the tip of the epiglottis with the endoscope) or nasal occlusion, were used as procedures to promote the full abduction of the arytenoid cartilages and/or DDSP (Hobo et al., 1995).

\section{Data analysis}

Data were stored in a database (Excel 2000, Microsoft Corp. Redmond, Whashington USA) and the statistical analyses were carried out using the Chi squared test (GraphPad Prism version 5.00, San Diego, California, USA) to determine whether there were any significant associations between the disorders, grades, age groups and complaints at the time of the endoscopic examination. The values were expressed as a percentage or as the mean \pm SEM, with a $p<0.05$ considered significant.

\section{RESULTS}

The present study analysed the endoscopic register of 385 2-year-old horses and 202 3-year-old-plus horses (overall mean age of 2.5 years).

Routine athletic follow up was the main indication for the endoscopic examinations, where this indication applied to 340 (57.9 \%) horses. Fifteen $(2.6 \%)$ horses were submitted to prepurchase examination, $83(14.1 \%)$ were examined as an investigation for cough, $58(9.9 \%)$ horses had poor performance, $48(8.2 \%)$ had abnormal respiratory noise, 35 (6.0\%) had 

- resting endoscopic findings in 587 horses

epistaxis and 8 (1.4\%) had nasal discharge.

In $314 \quad(53.5 \%) \quad$ endoscopic evaluations, at least one type of abnormality was found. A single abnormality was identified in 215 $(36.6 \%)$ horses, two abnormalities were seen in $96(16.3 \%)$, and three were found in $3(0.5 \%)$ horses.

The horses presenting for investigation of abnormal respiratory noise had at least one type of URT abnormality in 36 (75\%) cases. This finding was the highest percentage of positive diagnosis of all groups.

The most commonly observed abnormality was PLH grades III/IV. It was diagnosed in 198 (33.7\%) of the examined horses and was more prevalent in the 2-year-old group than in the older horses $(40.5 \%$ vs. $20.8 \%$, $p<0.05$, Table 1).

Table 1 - Prevalence of upper respiratory tract (URT) abnormalities in the two different age groups of evaluated horses. Results are demonstrated as number of horses and (\%).

\begin{tabular}{c|c|c}
$\begin{array}{c}\text { number of horses and (\%) } \\
\begin{array}{c}\text { Upper Airway } \\
\text { Disorder }\end{array}\end{array}$ & $\begin{array}{c}\text { 2-year-old horses } \\
(n=385)\end{array}$ & $\begin{array}{c}\text { 3-year-old plus older } \\
\text { horses }(n=202)\end{array}$ \\
\hline DDSP & $127(33)$ & $58(28.7)$ \\
\hline PLH III/IV & $156(40.5)^{\circ}$ & $42(20.8)$ \\
\hline RLN III & $7(1.8)$ & $6(3)$ \\
\hline RLN IV & $9(2.3)$ & $12(5.9)$ \\
\hline \multicolumn{2}{c}{ DDSP, dorsal displacement of the soft palate; RLN, recurrent laryngeal neuro pathy. }
\end{tabular}
$p<0.05$ vs. 3-year-old plus older group.

Additionally, horses with pharyngitis were more likely to have cough as the main complaint compared to the horses with PLH graded I and II. (Table 2).

Table 2 - Prevalence of upper respiratory tract (URT) abnormalities correlated with reason for the endoscopic examination. Results are demonstrated as number of horses and (\%).

\begin{tabular}{|c|c|c|c|c|}
\hline $\begin{array}{l}\text { Reason for } \\
\text { endoscopic } \\
\text { examination }\end{array}$ & $\begin{array}{c}\text { Pharyngitis } \\
(n=198)\end{array}$ & $\begin{array}{c}\text { DDSP } \\
(n=185)\end{array}$ & $\begin{array}{l}\text { RLN III } \\
(n=13)\end{array}$ & $\begin{array}{l}\text { RLN IV } \\
(n=21)\end{array}$ \\
\hline RAE & $115(58.1)$ & 99 (53.5) & $4(30.8)$ & $5(23.9)$ \\
\hline RN & $15(7.6)$ & $19(10.3)$ & $4(30.8)$ & $12(57.1)$ \\
\hline PP & $15(7.6)$ & $19(10.3)$ & $2(15.4)$ & $3(14.3)$ \\
\hline ND & $4(2.1)$ & $4(2.2)$ & $0(0.0)$ & $0(0.0)$ \\
\hline $\mathrm{Cg}$ & $43(21.7)^{2}$ & $32(17.3)$ & $1(7.7)$ & $0(0.0)$ \\
\hline Ex & $1(0.5)$ & $9(4.9)$ & $1(7.7)$ & $1(4.8)$ \\
\hline PPE & $5(2.5)$ & $3(1.6)$ & $1(7.7)$ & $0(0.0)$ \\
\hline
\end{tabular}

DDSP was identified in 185 $(31.5 \%)$ evaluated horses. Its prevalence was higher in horses with PLH grades III and IV than those with grades I or II $(43.4 \%$ vs. $25.4 \%, p<0.05$, (Table 3). An ulcer in the free edge of the soft palate was observed in 43 $(7.33 \%)$ evaluations. However, there was not a higher prevalence of cough or an increased PHL severity in these horses.

Table 3 - Correlation between dorsal displacement of soft palate (DDSP) and other upper airway disorders. Results are represented as number of affected horses per disorder (\%).

\begin{tabular}{l|c|c|c|c|c}
\hline $\begin{array}{l}\text { Upper } \\
\text { Airway } \\
\text { Disorder }\end{array}$ & $\begin{array}{c}\text { PLHI, II } \\
(n=389)\end{array}$ & $\begin{array}{c}\text { PLH III, IV } \\
(n=198)\end{array}$ & $\begin{array}{c}\text { RLN I, II } \\
(n=553)\end{array}$ & $\begin{array}{c}\text { RLN III } \\
(n=13)\end{array}$ & $\begin{array}{c}\text { RLN IV } \\
(n=21)\end{array}$ \\
\hline DDSP & $99(25.4)$ & $86(43.4)^{\circ}$ & $172(31.1)$ & $4(30.8)$ & $9(42.8)$ \\
\hline
\end{tabular}

RLN, recurrent laryngeal neuropathy. ${ }^{*} p<0.05$ vs. PLH I,II.

During evaluation of the arytenoid cartilage function, $462(78.7 \%)$ horses were graded as RLN I, 91 (15.5\%) were identified as Grade II, 13 (2.2\%) were identified as Grade III, and 21 (3.6\%) were identified as Grade IV. Sixteen horses (47.1\%) with RNL severity capable of compromising the athletic performance (Grades III and IV combined) had respiratory noise as main complaint for the endoscopic examination (Table 2).

\section{DISCUSSION}

The present study is a novel piece of research reporting the incidence of three major URT abnormalities in the TB South American race industry.

Recently, a considerable number of URT studies (Martin et al., 1999; Tan et al., 2005; Lane et al., 2006a; Lane et al., 2006b) have been performed using HSTM videoendoscopy. These studies have yielded the identification of dynamic airway obstructions like axial deviation of the aryepiglottic folds, dynamic pharyngeal collapse or and arytenoid collapse. This method provides substantial information about 
alterations that occur during exercise. However, analysis of the results regarding the prevalence of URT abnormalities obtained with those studies must be done with caution, for the reason that most were composed by horse populations referred for investigation of poor performance and/or respiratory noise, consequently increasing the probability of URT disorders being diagnosed. On the other hand, studies performed exclusively with horses in training that do not show clinical signs may underestimate the prevalence of disorders. In the present study, horses presented for investigation of clinical signs associated with respiratory diseases. Additionally, horses submitted to routine athletic and pre-purchase examinations were included.

Respiratory noise during exercise is specific for an upper airway problem. Poor performance can be caused by dysfunction in many systems (Derksen, 2005). In the present study, horses that presented for respiratory noise were more likely to have a URT abnormality identified during the endoscopic examination than horses presenting for poor performance (75\% vs. $49 \%)$. This was similar to the results obtained by Tan et al. (2005) (71\% vs. 43\%) in resting endoscopy prior to HSTM videoendoscopic exam.

Cough was the most prevalent clinical sign. Cough is a reflex elicited by the stimulation of receptors located in central airways from the larynx to the bronchi (Couëtil, 2007). Therefore, it can be related to different regions within the respiratory tract. Horses in which PLH grades III/IV and DDSP were diagnosed often had cough as the main complaint. This finding was supported by previous reports (Hobo et al., 1995; Art and Lekeux, 2005). The findings of this study reinforce the importance of these disorders in the differential diagnosis of cough.
PLH grades III/IV was the most commonly diagnosed abnormality. It was detected in $33.7 \%$ of the animals evaluated in the present study. This high prevalence may be explained by the low median age of the studied horse population. In the beginning of their training careers, horses are constantly and cumulatively exposed to new antigenic stimuli, and the proximity of the pharynx to the external environment predisposes it to inflammation (Holcombe, 2006). This finding tends to be less prevalent as horses get older. Hobo et al. (1995) reported a similar prevalence $(37 \%)$ that decreased to $0 \%$ in 6-year-old or older horses. An association between this disorder and age was also observed in the present study. The 2-year-old horses were approximately twice as likely to be affected by PLH grades III/IV than 3year-old or older horses. A correlation between PLH grades III/IV and poor performance was not found in this study, has reported previously (Auer et al., 1985).

The current study found that horses with PLH grades III/IV were significantly more prone to have DDSP observed during resting examination than horses graded PLH I/II. The ethiopathogenesis of DDSP is not completely clear, although it probably has multifactorial causes (Parente, 1998). It has been suggested that failure to maintain the airtight seal between the soft palate and laryngeal cartilage is due to a primary dysfunction of the neuromuscular regulation of the soft palate involving the pharyngeal branch of the vagus nerve and the palatinus and palatopharyngeus muscles (Holcombe, 1998). Therefore, the observations of this study suggest that pharyngeal inflammation could adversely affect the nervous branch that supplies the muscles controlling soft palate function, thus causing the occurrence of DDSP. 
DDSP was the most prevalent of the two URT obstructive diseases studied. The incidence found in our study $(31.5 \%)$ was somewhat lower than the results obtained by Hobo et al. (1995) in 3-year-old horses (37.6\%) but considerably higher than the results obtained in Australia by Brown et al. (2005) (0.5\%) and Tan et al. (2005) (2.2\%). Tan et al (2005) performed resting endoscopy prior to HSTM examination. Similar to the work of Hobo et al. (1995), stimulated swallowing and nasal occlusion were used in the current study as part of the examination protocol. Brown and colleagues (2005) did not include nasal occlusion and Tan et al (2005) did not report any procedures to induce DDSP.

The prevalence of DDSP has been stated to be higher in young horses (Dykgraaf et al., 2005; Lane et al., 2006a) probably due to structural immaturity of the nasopharynx (Robertson and Ducharme, 2005). DDSP is probably more frequent in 2 to 4 year-olds (Holcombe, 2006). There was no association between age and DDSP in this study, probably because the mean age of both groups studied fit within the reported age range. The mean age of the group of horses 3 years of age and older was 3.6 years.

Retracting the endoscope from the proximal aspect of the trachea induces DDSP in both normal horses and horses with naturally occurring DDSP. This procedure allows for observation of ulcers or redness on the caudal edge of the soft palate (Ducharme, 2008). The presence of an ulcer in the free edge of the soft palate is believed to be an indication of DDSP during exercise (Robertson and Ducharme, 2005; Holcombe, 2006). There were no correlations found with the complaints most frequently associated to DDSP (respiratory noise and poor performance). There were also no correlations between age or severity of
- resting endoscopic findings in 587 horses the other disorders analysed in horses where ulcers were observed.

DDSP is commonly associated with poor performance and characteristic expiratory sounds (Derksen et al., 2001; Robertson and Ducharme, 2005; Couëtil, 2007). Moreover, recent studies have reported poor correlation between the observation of DDSP in the resting horse and the occurrence of DDSP during exercise on HSTM (Tan et al., 2005; Lane et al., 2006b). In the current study, the majority of horses with DDSP presented for routine athletic examination $(53.5 \%)$, thus showing no characteristic clinical signs. It has been postulated that some horses diagnosed with DDSP during exercise do not generate abnormal respiratory sounds (Derksen et al., 2001), but the significant lack of association between this two important clinical signs and DDSP observed in this study may reinforce the poor correlation between the resting observation of DDSP and the occurrence of DDSP at exercise.

The RLN grading system used in this study provides substantial information regarding laryngeal function during exercise. By analyzing the findings of four studies comparing the outcome of resting endoscopy versus HSTM videoendoscopy in 461 horses, it was observed that $100 \%$ of horses with RNL Grade I and $96 \%$ of horses graded RNL II in the resting endoscopic examination had full abduction of the arytenoid cartilages during exercise (Ducharme, 2005). In the same study, $85 \%$ of the horses graded III RNL had some degree of arytenoid collapse. All horses graded IV RNL manifested collapse of the arytenoid cartilage during the HSTM exam. Therefore, the absence of full arytenoid cartilage abduction during the resting endoscopic exam was found to be the major reference point to differentiate horses that probably would have abnormal 
cartilage function during exercise. For the horses graded III RNL, the use of HSTM videoendoscopy would be helpful for triage, racing purposes or surgery.

Laryngeal hemiplegia (RNL Grade IV) was found in $3.6 \%$ of the evaluated horses in our study, similar to the $4.7 \%$ observed in the study of Lindegaard et al. (2007). This incidences were higher than the $0.3 \%$ prevalence found in the studies by Hobo et al. (1995) and Brown et al. (2005).

Moreover, RNL severity capable of compromising the athletic performance (Grades III and IV combined) was detected in $5.8 \%$ of the horses evaluated in the present study. In three different studies, the prevalence ranged between $1.6 \%$ and $15 \%$ (Hobo et al., 1995; Anderson et al., 1997; Brown et al., 2005). The same RNL graduation criteria were used in all studies. Therefore, discrepancies may reflect inter-observer variations or different inclusion criteria.

\section{CONCLUSION}

In conclusion, the present study reports the prevalence of three URT tract abnormalities in a population of racing TB horses in Curitiba, South of Brazil. The results of this study replicate preceding reports in TB racing populations examined in different countries. It confirms previous information that PLH grades III/IV is more frequent among younger horses, is not related to poor performance, and reinforces its probable implication in the ethiopathogenesis of DDSP. The poor correlation between the resting observation of DDSP and the clinical signs commonly associated to this disorder, suggests that the resting URT evaluation should be used with caution in the prediction of DDSP during exercise. Cough is an important clinical manifestation when upper airway disorders have to be included in the differential diagnosis.

This study acknowledges the importance of resting URT endoscopy in the equine veterinary practice, but also the limitation of not being able to accurately predict most of the functional alterations that occur during exercise. HSTM videoendoscopy is considered the gold standard for the evaluation of dynamic alterations of the URT but is still unavailable to many equine veterinary practitioners around the world. By reproducing natural exercising conditions, dynamic respiratory endoscopy without treadmill (Desmaizieres et al., 2009; Pollock et al., 2009) and spectrogram analysis of respiratory sounds (Derksen et al., 2001; Dornbusch et al., 2008) are expected to bring new light to the understanding of the physiopathology of the diseases affecting the URT during exercise, and may in the near future, be available complements to the resting endoscopic observation in many equine practices.

\section{REFERENCES}

ANDERSON, B.; KANNEGIETER, N.; GOULDEN, B. Endoscopic Observations on Laryngeal Symmetry and Movements in Young Racing Horses. New Zealand Veterinary Journal, v.45, p.188-192, 1997.

ART, T.; LEKEUX, P. Upper airway function and dysfunction. In: 9TH GENEVA CONGRESS ON EQUINE MEDICINE AND SURGERY, Geneva, 2005. Proceedings....Geneva, 2005. p. 30-33.

AUER, D.E.; WILSON, R.G.; GROENENDYK, S. Pharyngeal lymphoid hyperplasia in

Thoroughbred racehorses in training. Australian Veterinary Journal, v.62, n.4, p.124-126, 1985.

BROWN, J.; HINCHCLIFF, K.; JACKSON, M. et al. Prevalence of pharyngeal and laryngeal abnormalities in Thoroughbreds racing in Australia, and their association with performance. Equine Veterinary Journal, v.37, n.5, p.397-401, 2005. 
COUËTIL, L. Respiratory Diseases by Clinical Signs. In: LEKEUX, P. (Ed.), Equine

Respiratory Diseases. 2007. Disponível em: <http://www.ivis.org/special_books/Lekeux/couet il/chapter.asp? $L A=1>$. Acesso em: 06/09/2010.

DERKSEN, F.; HOLCOMBE, S.; HARTMANN, W. et al. Spectrum analysis of respiratory sounds in exercising horses with experimentally induced laryngeal hemiplegia or dorsal displacement of the soft palate. American Journal of Veterinary Research, v.62, n.5, p.659-664, 2001.

DESMAIZIERES, L.M.; SERRAUD, B.; PLAINFOSSE, B. et al. Dynamic respiratory endoscopy without treadmill in 68 performance Standardbred, Thoroughbred and saddle horses under natural training conditions. Equine Veterinary Journal, v.41, n.4, p.347-352, 2009.

DORNBUSCH, P.T.; LEITE, S.C.; CIRIO, S.M. et al. Análise dos ruídos respiratórios de cavalos atletas no diagnóstico da hemiplegia de laringe. Archives of Veterinary Science, v.13, n.3, p.184-190, 2008.

DUCHARME, N. Upper Airway: Clinical Perspectives. In: AINSWORTH, D.M.; McGORUM, B.C.; VIEL, L. et al. THIRD WORLD EQUINE AIRWAYS SYMPOSIUM, 2005, Ithaca, USA. Proceedings...Ithaca: Cornell University, 2005. p.68-73.

DUCHARME, N. Etiogenesis and diagnosis of DDSP. In: VETERINARY EUROPEAN EQUINE MEETING, Veneza, 2008.

Proceedings...Veneza, 2008. p.109-112.

DYKGRAAF, S.; MCILWRAITH, C.; BAKER, V. et al. Sternothyroideus Tenectomy Combination Surgery for Treatment of Dorsal Displacement of the Soft Palate in 96 Thoroughbred Racehorses (1996-2004). In: ANNUAL CONVENTION OF THE AMERICAN ASSOCIATION OF EQUINE PRACTITIONERS, Seattle, 2005.

Proceedings...Seattle: American Association of Equine Practitioners, 2005. p.323-326.

HOBO, S.; MATSUDA, Y.; YOSHIDA, K. Prevalence of upper respiratory tract disorders detected with a flexible videoendoscope in thoroughbred racehorses. The Journal of Veterinary Medical Science, v.57, n.3, p.409413, 1995.

HOLCOMBE, S.J.; DERKSEN, F.J.; STICK, J.A. et al. Effect of nasal occlusion on tracheal and pharyngeal pressures in horses. American
- resting endoscopic findings in 587 horses

Journal of Veterinary Research, v.57, n.9, p.1258-1260, 1996.

HOLCOMBE S. Neuromuscular regulation of the larynx and nasopharynx in the horse. In: ANNUAL CONVENTION OF THE AMERICAN ASSOCIATION OF EQUINE PRACTITIONERS, Baltimore, 1998. Proceedings...Baltimore: American Association of Equine Practitioners, 1998. p.26-29.

HOLCOMBE S. Upper Airway Anatomy and Physiology Gone Wrong: How Do We Diagnose the Problem and What Can We Fix? In: ANNUAL RESORT SYMPOSIUM OF THE AMERICAN ASSOCIATION OF EQUINE PRACTITIONERS, Rome, 2006.

Proceedings...Rome: American Association of Equine Practitioners, 2006. p.10-27.

LANE, J.; BLADON, B.; LITTLE, D. et al. Dynamic obstructions of the equine upper respiratory tract. Part 1: Observations during high-speed treadmill endoscopy of 600 Thoroughbred racehorses. Equine Veterinary Journal, v.38, n.5, p.393-399, 2006a.

LANE, J.; BLADON, B.; LITTLE, D. et al. Dynamic obstructions of the equine upper respiratory tract. Part 2: Comparison of endoscopic findings at rest and during highspeed treadmill exercise of 600 Thoroughbred racehorses. Equine Veterinary Journal, v.38, n.5, p.401-407, 2006b.

LINDEGAARD, C.; HUSTED, L.; ULUM, H. et al. Sedation with detomidine and acepromazine influences the endoscopic evaluation of laryngeal function in horses. Equine Veterinary Journal, v.39, n.6, p.553-556, 2007.

MARTIN, B.; REEF, V.; PARENTE, E. et al. Clinical evaluation of poor training or racing performance in 348 Horses (1992-1996). In: ANNUAL CONVENTION OF THE AMERICAN ASSOCIATION OF EQUINE PRACTITIONERS, Albuquerque, 1999.

Proceedings...Albuquerque: American Association of Equine Practitioners, 1999. p.322324.

ORDIDGE, R. The Treatment of Dorsal Displacement of the Soft Palate by Thermal Cautery: A Review of 252 Cases. In: VIEL, L.; ROBINSON, N.E.; DUCHARME, N.G. et al. Second World Equine Airways Symposium. Edinburgh, Scotland. Proceedings...Edinburgh, 2001. Disponível em <http://www.ivis.org/proceedings/weas/2001/Ord idge.pdf>. Acesso em 02/02/2011. 
PARENTE, E. Value of high speed treadmill endoscopy. In: ANNUAL CONVENTION OF THE AMERICAN ASSOCIATION OF EQUINE PRACTITIONERS, Baltimore, 1998.

Proceedings...Baltimore: American Association of Equine Practitioners, 1998. p.30-33.

POLLOCK, P.J.; REARDON, J.M.; PARKIN, T.D.H. et al. Dynamic respiratory endoscopy in 67 Thoroughbred racehorses training under normal ridden exercise conditions. Equine Veterinary Journal, v.41, n.4, p.354-360, 2009.

RAKER, C.; BOLES, C. Pharyngeal lymphoid hyperplasia in the horse. Journal of Equine Medicine and Surgery, v.2, p.202-207, 1978.

RAKESTRAW, P.; HACKETT, R.; DUCHARME, N. et al. Arytenoid cartilage movement in resting and exercising horses. Veterinary Surgery, v.20, n.2, p.122-177, 1991.

ROBERTSON, J.; DUCHARME N. Disorders of the Pharynx and Larynx In: LEKEUX, P. (Ed.), Equine Respiratory Diseases. 2005.

Disponível em:

<http://www.ivis.org/special_books/Lekeux/rober tson/chapter.asp? LA=1>. Acesso em: 10/01/2011.

SÁNCHEZ, A.; COUËTIL, L.; WARD, M. et al. Effect of airway disease on blood gas exchange in racehorses. Journal of Veterinary Internal Medicine, v.19, n.1, p.87-92, 2005.

TAN, R.; DOWLING, B.; DART, A. High-speed treadmill videoendoscopic examination of the upper respiratory tract in the horse: The results of 291 clinical cases. The Veterinary Journal, v.170, n.2, p.243-248, 2005. 